\title{
Communication
}

[Comunicação]

\section{First record of Neobenedenia melleni (Monogenea: Capsalidae) in dog snapper (Lutjanus jocu) in the western South Atlantic}

\author{
[Primeiro registro de Neobenedenia melleni (Monogenea: Capsalidae) em dentão \\ (Lutjanus jocu) no oeste do Atlântico Sul] \\ B.L. Oliveira ${ }^{1}$, R.M. Souza ${ }^{2}$, L.C. Gomes ${ }^{3}$, L.F.L. Fernandes ${ }^{4}$ \\ ${ }^{1}$ Aluno de pós-graduação - Universidade Federal do Espírito Santo (UFES) - Aracruz, ES \\ ${ }^{2}$ Universidade Federal do Espírito Santo (UFES) - Aracruz, ES \\ ${ }^{3}$ Universidade Vila Velha (UVV) - Vila Velha, ES \\ ${ }^{4}$ Universidade Federal do Espírito Santo (UFES) - Vitória, ES
}

Snappers (Lutjanidae) can be found in tropical and subtropical waters of the Atlantic, Indian and Pacific Oceans and have high commercial demand and high added value. In addition, snappers are hardy and adaptable to aquaculture, with some well-established species and others being studied in coastal and oceanic regions (Ibarra-Castro and Duncan, 2007). Dog snapper, Lutjanus jocu (Bloch and Schneider, 1801), can be found in continental shelf areas of the western Atlantic Ocean and feeds preferentially on fish, shrimp, crabs, cephalopods and gastropods. It is of great importance in Brazilian fishing and is considered fully exploited and vulnerable to the effects of overfishing (Froese and Pauly, 2019).

Little information on parasitism in $L$. jocu is available, especially when related to maintenance in farming systems, with the exception of its classification as susceptible to Epibdella melleni after an infestation in a New York aquarium (Jahn and Kuhn, 1932). E. melleni was later described as Neobenedenia melleni by Yamaguti (1963) and occurs in more than 100 species of wild or captive teleosts with low specificity and high pathogenicity (Whittington and Horton, 1996). Under experimental or culture conditions, $N$. melleni is highly efficient in acquiring a host and in reproduction and can be reproduced using a single individual. Thus, N. melleni is recognized as a severe and lethal threat that can

Recebido em 15 de julho de 2019

Aceito em 17 de outubro de 2019

E-mail: brunodlo@yahoo.com.br cause great harm to the producers (Militz et al., 2014).

The present study aimed to describe the first record of Neobenedenia melleni in dog snapper (L. jocu) in the western South Atlantic. Procedures for the elimination of this parasite in fish reared in the laboratory are also suggested.

Forty specimens of $L$. jocu $(280 \pm 104 \mathrm{~g}$ and 25.7 $\pm 3.5 \mathrm{~cm}$ ) were captured in the estuary of the Piraque-Açu River, Aracruz/ES, Brazil (1956'S $40^{\circ} 10^{\prime} \mathrm{W}$ ), using a gill net (Authorization for activity for scientific purposes by ICMBio SISBIO number 52082-2) and transported in plastic boxes with $100 \mathrm{~L}$ of water and aeration to the Laboratory of Cultivation of Marine Organisms of the Federal University of Espírito Santo (Protocol 96/2015 of the Ethics Committee on the Use of Animals CEUA/UFES). One specimen was deposited in an ichthyological collection (CIUFES 3553). The fish were acclimated and transferred to two 6000L circular tanks in a climate-controlled room with a water recirculation system, where they were kept under observation. Feeding was provided daily (5\% of the biomass) using a mixture of chopped sardines, squid and shrimp.

The physicochemical parameters of water quality were measured daily using a multiparameter meter and maintained at a temperature of $23.51 \pm$ $0.26^{\circ} \mathrm{C}$, pH of $7.82 \pm 0.21$, dissolved oxygen of 


\section{Oliveira et al.}

$5.69 \pm 0.11 \mathrm{mg} / \mathrm{L}$, salinity of $34.85 \pm 0.15$ and photoperiod of 12-12 hours. A photocolorimeter was used to quantify the levels of ammonia, nitrite and nitrate, which were $0.05 \pm 0.15,0.91$ \pm 0.60 and $0.32 \pm 0.20 \mathrm{mg} / \mathrm{L}$, respectively.

The first symptoms of abnormality appeared after 40 days, with approximately half of the individuals showing lack of appetite and erratic and lethargic swimming. Five days after the onset of symptoms, the clinical condition worsened, with exophthalmia, eye opacity or hemorrhage, sudden movements of disorientation, mucus hypersecretion, color changes. Signs of secondary infection by bacteria were also observed, such as hemorrhagic lesions (ulcers) and erosion of the fins and gills (Figure 1 ), which are strong indicators of the presence of ectoparasites, as observed by Hoa and Ut (2007) and Sanches and Viana (2007).
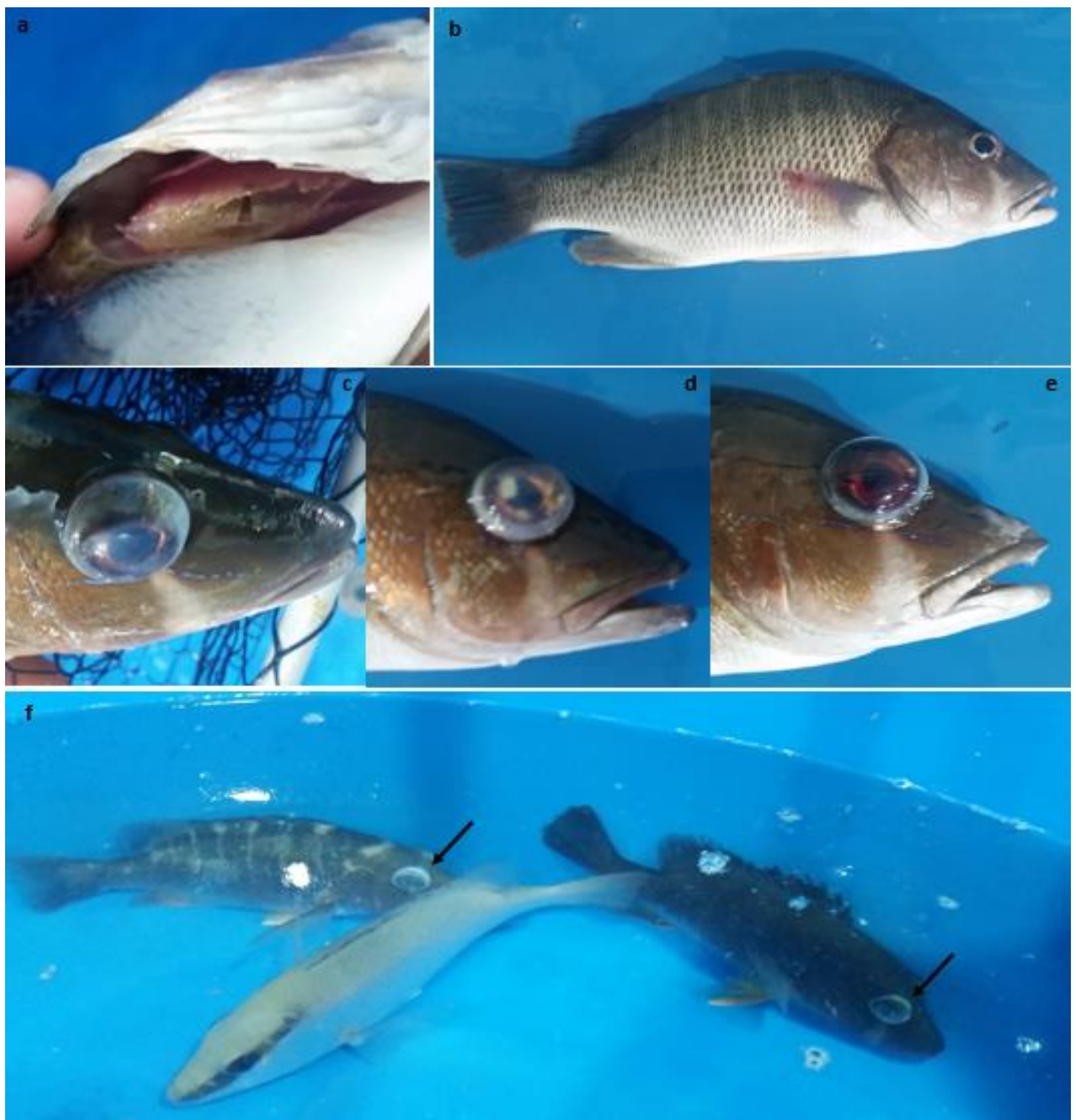

Figure 1. Symptoms of abnormalities in Lutjanus jocu parasitized by Neobenedenia melleni arising after 40 days of culture. Exemplar showing gill erosion (a) and pectoral fin erosion (b). Eye physiognomy comparison: (c) exophthalmia; (b) opacity and exophthalmia; (c) opacity, exophthalmia and intraocular hemorrhage. Color change in fish with exophthalmia (f). 
The treatment consisted of keeping the fish in a box $(500 \mathrm{~L})$ with freshwater for $15 \mathrm{~min}$, adapted from Sanches and Viana (2007). No fish mortality occurred during the exposure, but before the end of the exposure, it was possible to observe the whitish color of the parasites in the fish body, especially in the caudal and dorsal fins, caudal peduncle and eyeball; detachment of the parasites from the fish body; and parasites in the water column at the bottom of the box where the treatment was performed. The parasites were collected, fixed (Justine et al., 2012), quantified, analyzed under a stereoscopic microscope and, using the identification key proposed by Whittington and Horton (1996), identified as $N$. melleni (Figure 2). The parasites were then measured under a trinocular microscope with image capture and software.

Approximately 82 parasites were found per fish, with a total length of $2000-5000 \mu \mathrm{m}$. The large number of parasites found in the fish is the result of the temperature and salinity in which they were kept in the laboratory. The salinity provided a faster life cycle, and the temperature facilitated attachment of the parasite to the host, egg production and egg length, similar to observations reported by Brazenor and Hutson (2015). Then, 48 hours after the first freshwater bath, a second bath was performed, and a complete absence of parasites in the fish and water was observed.

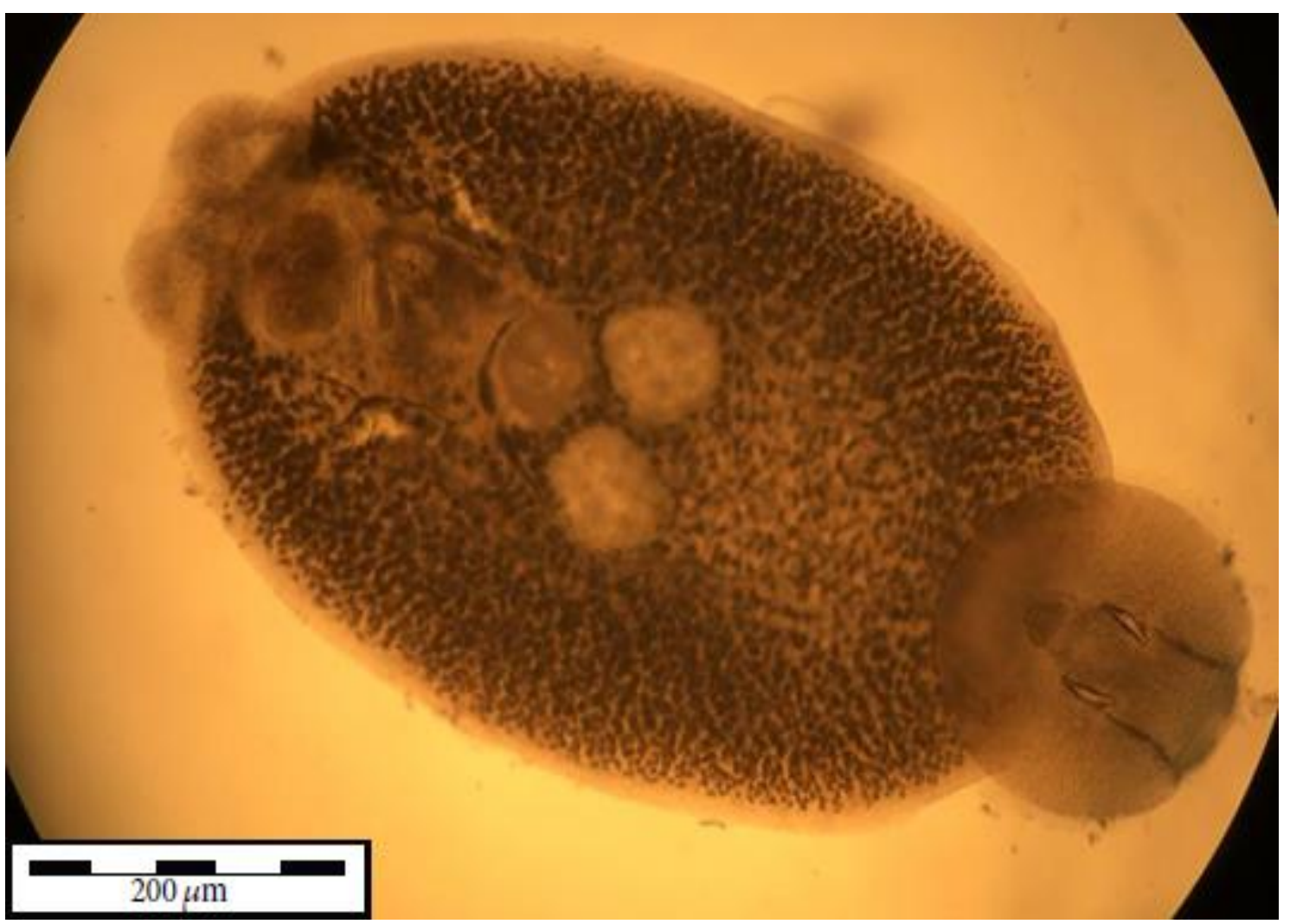

Figure 2. Neobenedenia melleni MacCallum, 1927 (Monogenea: Capsalidae) specimen measured under a microscope. The specimen was collected in Lutjanus jocu after 40 days of culture in the laboratory.

N. melleni is a pathogen with a wide distribution and high potential to cause economic losses in marine teleost cultures. N. melleni has been reported in captive and wild fish in the Caribbean Sea, Western Atlantic Ocean, Eastern and Central Pacific Ocean, Red Sea (Whittington and Horton, 1996) and Australia in farmed Lates calcarifer (barramundi), which resulted in mortality of more than 200,000 fish (Deveney et al., 2001). In Brazil, Kerber et al. (2011) reported $N$. melleni for the first time in farmed cobia (Rachycentron canadum), and Sanches and Viana (2007) reported $N$. melleni in the cultivation of the dusky grouper (Epinephelus marginatus). There are few records of infection of snappers in the literature, with some reports 
by Hoa and Ut (2007) in Lutjanus argentimaculatus cultured in Vietnam and Ravi and Yahaya (2016) in Lutjanus erythropterus cultured in Malaysia. The current study presents the second record of $N$. melleni in $L$. jocu in captivity and the first record of this species in the western South Atlantic, considerably expanding its geographical distribution.

The commercial culture of snappers is growing considerably in the Neotropical region (Central America and the Caribbean), and several research studies in South America and the United States have demonstrated their importance and potential for aquaculture (CastilloVargasmachuca et al., 2018). With the growth of marine fish farming in Brazil, greater care is needed regarding the identification and treatment of the main pathologies in this type of culture. Among the treatments used for infestations with monogenoids, the exposure time in freshwater differs between marine fish species in a period that can vary from $5 \mathrm{~min}$ (Sanches and Viana, 2007) up to $60 \mathrm{~min}$ (Fajer-Ávila et al., 2008), and immersion for $15 \mathrm{~min}$ was effective for dog snapper.

The rapid identification of parasitic fauna in fish collected in a natural environment and transported to farming sites, often under high density, and prophylactic actions for their elimination are essential for the sanitary control of farmed fish. The threat posed by monogenoids for marine fish farming should always be considered. Thus, prior knowledge of the parasitic fauna of a possible farmed fish is essential, especially for the diagnosis, control and management of possible parasitic diseases.

Keywords: aquaculture, Brazil, ectoparasites, pathology

\section{RESUMO}

Neobenedenia melleni (MacCallum, 1927) (Monogenea) é um patógeno amplamente distribuído em cultivo de teleósteos marinhos no mundo. Com o crescimento da piscicultura marinha no Brasil, faz-se necessário um maior cuidado em relação à identificação e ao tratamento das principais patologias nesse tipo de cultivo. Este estudo relata a primeira ocorrência de Neobenedenia melleni em dentão (Lutjanus jocu) no oeste do Atlântico Sul. Também são sugeridos procedimentos adotados para eliminação desse parasito em peixes cultivados em laboratório.

Palavras-chave: aquicultura, Brasil, ectoparasitos, patologia

\section{ACKNOWLEDGEMENTS}

To Coordenação de Aperfeiçoamento de Pessoal de Nível Superior (CAPES) - Financing Code 001, for supporting the first author with a postgraduate fellowship. To Fundação de Amparo à Pesquisa e Inovação do Espírito Santo (FAPES) and CAPES supporting the second author (PROFIX FAPES/CAPES09/2014, process no. 72358173). To FAPES for financial support (process no. 698/2016, FAPES/ SEAG no. 06/ 2015-PPE Agro).

\section{REFERENCES}

BRAZENOR, A.K.; HUTSON, K.S. Effects of temperature and sanlinity on the life cycle of Neobenedenia sp. (Monogea: Capsalidae) infecting farmed barramundi (Lates calcarifer). Parasitol. Res., v.115, p.1875-1886, 2015.
CASTILLO-VARGASMACHUCA, S.G.; PONCE-PALAFOX, J.T.; ARÁMBULMUÑOZ, E. et al. The spotted rose snapper (Lutjanus guttatus Steindachner 1869) farmed in marine cages: review of growth models. Rev. Aquacul., v.10, p.376-384, 2018.

DEVENEY, M.R.; CHISHOLM, L.A.; WHITTINGTON, I.D. First published record of the pathogenic monogenean parasite Neobenedenia melleni (Capsalidae) from Australia. Dis. Aquat. Organ., v.46, p.79-82, 2001.

FAJER-ÁVILA, E.J., MARTÍNEZRODRÍGUEZ, I., DE LA PARRA, M.I.A. et al. Effectiveness of freshwater treatment against Lepeophtheirus simplex (Copepoda: Caligidae) and Neobenedenia sp. (Monogenea: Capsalidae), skin parasites of bullseye puffer fish, Sphoeroides annulatus reared in tanks. Aquaculture, v.284, p.277-280, 2008. 
FROESE, R.; PAULY, D. FishBase. World Wide Web electronic publication. 2019. Available in: <http://www.fishbase.org> versão 04/2019. Accessed in: 2 Abr. 2019.

HOA, D.T.; UT, P.V. Monogean disease in cultured grouper (Epinephelus spp.) and snapper (Lutjanus argentimaculatus) in Khanh Hoa Province, Vietnam. Aquacul. Asia Mag., v.12, p.40-42, 2007.

JAHN, T.L.; KUHN, L.R. The Life History of Epibdella Melleni Maccallum 1927, A monogenetic trematode parasitic on marine fishes. Biol. Bull., v.62, p.89-111, 1932.

IBARRA-CASTRO, L.; DUNCAN, N.J. GnRHa-induced spawning of wild-caught spotted rose snapper Lutjanus guttatus. Aquaculture, v.272, p.737-746, 2007.

JUSTINE, J.L.; BRIAND, M.J.; BRAY, R.A. et al. A quick and simple method, usable in the field, for collecting parasites in suitable condition for both morphological and molecular studies. Parasitol. Res., v.111, p.341-351, 2012.

KERBER, C.E.; SANCHES, E.G.; SANTIAGO, M.; LUQUE, J.L. First record of Neobenedenia melleni (Monogenea: Capsalidae) in sea-farmed cobia (Rachycentron canadum) in Brazil. Rev. Bras. Parasitol. Vet., v.20, p.331-333, 2011.

MAcCALLUM, G.A. A new ectoparasitic trematode, Epibdella melleni sp. nov. Zoopathologica 1, p.291-300, 1927.
MILITZ, T.A.; SOUTHGATE, P.C.; CARTON A.G. et al. Efficacy of garlic (Allium sativum) extract applied as a therapeutic immersion treatment for Neobenedenia sp. management in aquaculture. J. Fish Dis., v.37, p.451-461, 2014.

RAVI, R.; YAHAIA, Z.S. Neobenedenia melleni parasite of red snapper, Lutjanus erythropterus, with regression statistical analysis between fish length, temperature, and parasitic intensity in infected fish, cultured at Jerejak Island, Penang, Malaysia. J. Parasitol. Res., v.2016, 2016. Accessed in: 6 Mai. 2019.

SANCHES, E.G.; VIANNA, R.T. Ocorrência de Neobenedenia melleni (Monogenea: Capsalidae) em garoupa-verdadeira Epinephelus marginatus (Lowe, 1834) cultivada em tanques-rede. Arq. Ciênc. Mar, v.40, p.96-100, 2007.

WHITTINGTON, I.D.; HORTON, M.A. A revision of Neobenedenia Yamaguti, 1963 (Monogenea: Capsalidae) including a redescription of $N$. melleni (MacCallum, 1927) Yamaguti, 1963. J. Nat. Hist., v.30, p.1113-1156, 1996.

YAMAGUTI, S. Systema Helminthum, Vol. IV. Monogenea and Aspidocotylea. John Wiley and Sons, Interscience Publishers, New York, p.699, 1963. 